DOI https://doi.org/10.30525/978-9934-26-182-4-26

\title{
PRENATAL ANTIGENIC INFLUENCE OF STAPHYLOCOCCAL TOXOID INTO THE THYROID GLAND MORPHOGENESIS
}

\author{
Fedosieieva O. V. \\ Candidate of Medical Sciences, Associate Professor, \\ Associate Professor at the Histology, Cytology and Embryology Department \\ Zaporizhzhia State Medical University \\ Zaporizhzhia, Ukraine
}

Immunological autotolerance is induced during the perinatal period, when immature lymphocytes in the thymus are exposed to their own antigens $[1,2]$. At this crucial point, clonal deletion or induced energy of autoreactive T cells determines autotolerance to autoantigens. However, these mechanisms are not unique, and some autoreactive cells may exist in the body normally [3, 4]. Antigenic load at critical times of ontogenesis can cause significant "breakdowns" in the child's immune system. The consequence of transferred infections may be the initiation of morphological changes in organs and barrier structures, ie these infections may not lead to permanent changes in structure, but only leave a permanent immunological "background" in the body and the body as a whole. initiate pathological conditions $[5,6]$.

Infectious pathogens play a key role in the development of pathological conditions of the thyroid gland [7, 8]. The general influence of infectious loading on an immune system of an organism, and as a result, development of autoimmune states of a thyroid gland is considered. Infectious agents (bacterial, viral, fungal, spirochetes, etc.) can initiate responses to the thyroid gland through a variety of mechanisms, inducing modifications of their own antigens, mimicking car molecules, altering the idiotypic network, forming immune complexes and inducing thyrocytes $[9,10]$. Tissue damage in autoimmune diseases of the thyroid gland is influenced by both cell-mediated and humoral response of the immune system. T-lymphocytes are the main effects of the adaptive immune system and are crucial for protecting the body from pathogenic infectious agents. Aberrant $\mathrm{T}$ lymphocytes play a viral role in the pathogenesis of autoimmune conditions, not only helping the B cell to produce autoantibodies, but also penetrating the tissues of the body, which contributes to its immunopathology. The study of the structural equivalent of the above processes using pathomorphological methods and is the essence of the morphological mechanisms of autoimmune thyroiditis. This is too complex a problem both theoretically and methodologically, so it needs further research. 
Purpose. The paper was aimed at the study of the ultrastructural changes in the thyroid gland of experimental rats in postnatal period at norm and after prenatal influence of staphylococcal toxoid.

Material and Methods. As a experimental material were thyroid glands of Wistar rats aged 1 to 60 days of postnatal development (162 animals), about 6 animals in each group. The animals were kept in standard vivarium conditions. All experiments carried out in strict accordance with the national "Common ethical principles of animal experiments "(Ukraine, 2001), which are consistent with Council Directive 2010 / 63EU of the European Parliament and of the Council of 22 September 2010 on the protection of animals used for scientific purposes (Council Directive 2010 / 63EU of the European Parliament and of the Council of 22 September 2010 on the protection of animals used for scientific purposes). Three animals groups were studied on 1, 3, 7, 11, 14, 21, 30, 45, 60 days after bith. I gr. - intact animals (norm); II gr. - control, animals which were injected intrauterine $0.9 \% \mathrm{NaCl}$ solution; III - experimental animals injected with staphylococcal toxoid liquid purified adsorbed (10-14 units of binding in 1 $\mathrm{ml}$, diluted 10 portions) by operation intrauterinely on the 18th day of dated pregnancy. Injections of antigen or $0.9 \% \mathrm{NaCl}$ solution for fetus were performed surgically during laparotomy, by intrauterine, transdermal subcutaneous at a dose of $0.05 \mathrm{ml}$ to each fetus.

The thyroid gland was fixed in a $10 \%$ solution of neutral buffered formalin during the day. The objects were filled into paraffin blocks by the conventional method. Histological sections 3-5 $\mu \mathrm{m}$ thick were stained by hematoxylin and eosin, histochemicaly by alcian blue and azan staining. For electronic microscopy small pieces of the thyroid gland were recorded in $2.5 \%$ glutaraldehyde solution, treated with $1 \%$ osmium tetroxide solution, performed due to alcohols of increasing concentration, contrasted for two hours in $2.5 \%$ uranyl acetate on $70 \%$ alcohol, dehydrated in absolute alcohol and acetone and flooded in epon. Semi-thin $(1-2 \mu \mathrm{m})$ and ultra-thin $(55-65 \mathrm{~nm})$ sections were obtained on ultratomy PowerTome RMC Boeckeler (USA). Semi-thin sections were stained methylene blue, and ultrathin contrasting lead citrate according to Reynolds for a quarter of an hour at room temperature. Ultrathin sections were examined in the electron microscope PEM-100-01 at an accelerating voltage of $75 \mathrm{kV}$.

A set of morphometric studies was performed by microscope Carl Zeiss Primo Star equipped with the Axiocam digital microphoto attachment with using program complex Zeiss Zen 2011. Significance of differences between means was assessed using parametric Student's t-test with normal distribution and non-parametric U-test Manna-Whitney - with an abnormal distribution and was considered statistically significant at confidence levels of at least $95 \%$ (p 
$<0.05)$. For processing of statistical material was used the standard software package Microsoft Office Excel (Microsoft Office, USA) and Statistica 13.0 (TIBCO Software Inc., № JPZ804I382130ARCN10-J).

Results and Discussion. In the animals of control group, the thyroid follicular cells were cuboidal or cylindrical and were lying on a thin basement membrane. Histological and ultrastructural studies of the thyroid tissue of experimental animals in early suckling life period (6-21 day) demonstrated that infiltrates, which formed in thyroid after prenatal staphylococcal toxoid exposure, were composed of lymphocytes, plasma cells, or transformed lymphocytes that showed features intermediate between those of lymphocytes and plasma cells. Immunocytes do not pass through the follicular cells. Indeed, these cells can travel between the epithelial cells in other parenchymal organs in a manner similar to the neutrophil emigration (diapedesis) through the vessel wall. These immune cells were observed to travel from the stroma to the follicular lumen in a vectorial manner-similar to neutrophilic chemotaxis in acute inflammation. The basement membrane around the thyroid follicles remained intact around some follicles whereas it was reduplicated or focally increased in thickness around others. The basement membrane material seemed to have been secreted by the follicular cells, and strands of early collagen fiber formation were seen within the excess basement membrane material. Varied degrees of apoptosis were observed in thyroid gland of experimental animals. The basement membrane of the follicles was thickened by deposition of numerous collagen fibres. The thyrocytes had irregular cell nuclei and an increased number of mitochondria in the basal pole. Different stages of thyrocyte degeneration were visible at the sites of contact between lymphocytes or plasma cells and thyrocytes. The nuclei of dying thyroid cells were deformed, the cisterns of the endoplasmic reticulum were swollen, and the cell membrane disrupted. Cells from this area showed an increased number of cytoplasmic filaments, bundles of tonofilaments, large desmosomes, an increased number of desmosomes, and intracellular desmosomes. The colloid content of the follicles was diminished, and it seemed that instead of secreting the protein colloid, the follicular cells were producing either excessive proteinaceous material similar to colloid or other types of proteins. Thyroid follicles were widely separated, and contained only a small amount of vacuolated colloid.

Conclusion. Ultrastructural examinations of thyroid sections sampled from experimental animals after prenatal staphylococcal toxoid exposue suggest the following stages of process damage of thyroid foliccles and thyrocytes: thickening of the basement membrane caused by collagen deposition, thyrocyte apoptosis, stimulation of lymphocytes and plasma cells to cytotoxic reactions, and degeneration of thyrocytes damaged by the cytotoxic reaction. Thus, there 
is an adaptogenic immune-stimulated intracellular and structural rearrangement of the thyroid gland, which is configured to normalize and maintain intraorganic homeostasis and compensatory adaptive functional activity of the thyroid gland.

We suggest that this change in the rate and pathways of organ morphogenesis and aberrant morphogenetic crosses may increase the risk of developing pathological conditions of the thyroid gland under the influence of trigger factors during these periods, which is the purpose of further study.

\section{References:}

1. Jonsdottir B., Lundgren M., Wallengren S., Lernmark A., Jönsson I., Elding Larsson H., \& DiPiS Study Group. Are Perinatal Events Risk Factors for Childhood Thyroid Autoimmunity?. European thyroid journal. 2017. № 6 (6). P. 298-306.

2. Талапова П.С., Сорокіна І.В. (). Морфофункціональний стан щитовидної залози плода на тлі материнсько-плодових інфекцій, що спричинені Escherichia coli, Staphylococcus aureus i Klebsiella pneumonia. Патологія. 2021. Вип. 18 (1). С. 86-95.

3. Liu P. The immunologic status of newborns born to SARS-CoV-2-infected mothers in Wuhan, China. J. Allergy Clin. Immunol. 2020. Vol. 146 (1). P. 101-109.

4. Ajjan R.A., Weetman A.P. The pathogenesis of Hashimotos thyroiditis: further developments in our understanding. Horm. Metab. Res. 2015. Vol. 47 (10). P. 702-710.

5. Da Silva E., Jamur M., Oliver C. Mast cell function: a new vision of an old cell. J. Histochem. Cytochem. 2014. Vol. 62. P. 698-738.

6. Gilfillan A.M., Beaven M.A. Regulation of mast cell responses in health and disease. Crit. Rev. Immunol. 2011. Vol. 31 (6). P. 475-529.

7. Brown M.A., Hatfield J.K. Mast cells are important modifiers of autoimmune disease: with so much evidence, why is there still controversy?. Front. Immun. 2012. Vol. 3. P. 147.

8. Lu L.F., Lind E.F., Gondek D.C. [et al.]. Mast cells are essential intermediaries in regulatory T-cell tolerance. Nature. 2006. Vol. 442. P. 997-1002.

9. Fedosieieva, O.V. Morphogenesis of rat's thyroid gland in preweaning period after prenatal influence of staphylococcal toxoid. World of Medicine and Biology. 2020. Vol. 3 (73). P. 230-234.

10. Kambayashi T., Allenspach E.J., Chang J.T. [et al.]. Inducible MHC class II expression by mast cells supports effector and regulatory cell activation. J. Immunol. 2009. Vol. 182 (8). P. 4686-4695. 